\title{
Study of water hyacinth (Eichhornia crassipes) on the quality of cow dung biogas
}

\author{
D. V. Adegunloye \\ Department of Microbiology, Federal University of Technology, Nigeria
}

\begin{abstract}
The objective of this research was to know the effect of water hyacinth (Eichhornia crassipes) on the quality of cow dung biogas. Water hyacinth (Eichhornia crassipes) is a perennial aquatic herb, which belongs to the family Pontedericeae. It is usually found floating freely on the surface of fresh water or can be anchored in mud. Using water hyacinth as a biogas is one of the ways to limit the disadvantageous effects of the plant and to provide a low-cost gas. Seventy five percent cow dung was mixed thoroughly with $25 \%$ blended water hyacinth $(3: 1)$ and cleaned water was added to form slurry, it was poured through the inlet orifice of a digester. Bacteria and mould counts of the materials were determined before and during digestion. Temperature, $\mathrm{pH}$, of the digesting materials, biochemical and morphological characterization of the isolates were carried out to know the microorganisms responsible for the digestion of the materials. A total of eight (8) bacteria and four (4) fungi were isolated during digestion. The bacteria identified were Escherichia coli, Methanococcus mazei, Enterobacter aerogenes, Clostridium welchii, Methanobacterium ruminantium, Lactobacillus delbrueckii, Methanothrix sochngenii, Klebsiella pneumoniae and the fungi isolated included Aspergillus flavus, Aspergillus niger, Aspergillus fumigatus and Mucor mucedo. The $\mathrm{pH}$ of the digesting material was between 5.40 and 7.28. The temperature was from $30^{\circ} \mathrm{C}$ to $39^{\circ} \mathrm{C}$. The result of the biogas analysis was $91.10 \%$ methane $\left(\mathrm{CH}_{4}\right)$, other traced gases was $6.43 \%$, while ammonia $\left(\mathrm{NH}_{3}\right)$ was not detected. Twenty five percent $(25 \%)$ water hyacinth added to the seventy five percent cow dung in ratio 3:1 showed that water hyacinth could be mixed with cow dung to improve the methane quality of the biogas. This could contribute to the reduction of environmental pollution.

Keywords: assessment, biogas, cow dung, environment, quality, methane, $p H$, temperature, water hyacinth.
\end{abstract}




\section{Introduction}

Water hyacinth (Eichhornia crassipes) is a perennial aquatic herb, which belongs to the family Pontedericeae. It is usually found floating freely on the surface of fresh water or can be anchored in mud. Using water hyacinth as a feed is one of the methods to limit the disadvantageous effects of the plant and to provide a low-cost ingredient in animal diets. Thus, water hyacinth is considered to be a plant for hunger and poverty alleviation in several developing countries. Pollutants from urban, industrial and agricultural activities provide essential nutrients for the growth of this aquatic macrophyte. In Tanzania the plant has been identified in rivers Pangani and Sisi, Lake Victoria and in the Mtera hydro-electric dam (Joyce [1]). Leaves are deep green, large and erect. Roots are variable in length from about 10 to $90 \mathrm{~cm}$ long (Reza and Khan [2]). The rhizomes are generally 1 to 25 $\mathrm{cm}$ long, occasionally producing internodes. The plant is luxuriant in growth and multiplies very rapidly. The average height of the plant is about $45 \mathrm{~cm}$ in mature stage but generally ranges from 30 to $70 \mathrm{~cm}$ (Reza and Khan [2]). The plant is characterized by formation of large floating mats that normally cover the water surface. When allowed to propagate, it quickly colonizes vast areas of water masses causing a number of problems. Some examples of detrimental effects include loss of fishing ground, provision of habitats for mosquito and bilharzias breeding, occlusion of waterways for navigation, interference with hydroelectric power sources and suppression of other useful aquatic life (Hentges et al. [3] and El-Serafy et al. [4]). In Lake Victoria the menace caused by water hyacinth has prompted East African governments' action to control the spread of the plant by biological methods (Wulf and Andjelic [5]).

Cow dung is the undigested residue of herbivorous matter which has passed through the animal's gut. The resultant faecal matter is rich in minerals. Colour ranges from greenish to blackish, often darkening in colour soon after exposure to air. The composition of cow dung gas is approximately 55-60\% methane, 5-10\% hydrogen and 30-35\% carbon dioxide (Subba Rao [6]). Microorganisms have been known to digest organic materials such as solid wastes under strictly anaerobic conditions, to generate combustible gas (biogas) with manure or other materials being produced contemporarily as a by-product. Millions of cubic meters of methane in the form of swamp gas and biogas are produced every year by the decomposition of organic matter, both animal and plants. It is almost identical to the natural gas pumped out of the ground by the oil companies used by many for heating in houses and for cooking. The idea for the manufacturing of gas brought to the UK in 1895 by producing wood gas from wood and later coal. The resulting biogas was used for gas lighting in street lamps and homes. Biogas typically refers to a gas produced by the biological breakdown of organic matter in the absence of oxygen. Biogas originates from biogenic material and is a type of biofuel. One type of biogas is produced by anaerobic digestion or fermentation of biodegradable materials such as biomass, manure, sewage, municipal waste, green waste, plant material and energy crops (Anaerobic digestion factsheet). This type of biogas comprises primarily methane and carbon dioxide. 
This study aims to investigate the possibility of utilising water hyacinth and cow dung to improve the quality of the methane of biogas and to determine the microbial population, identify the microorganisms responsible for digestion, determine the optimum temperature and $\mathrm{pH}$ under which the gases are produced by microorganisms.

\section{Materials and methods}

The samples used for this work were cow dung and water hyacinth. Fresh cow dung was collected into a sterile polythene bag from the Department of Animal Production and Health Farm of The Federal University of Technology, Akure, Ondo State. Water hyacinth was collected from sea coastlines at Ilaje, Ondo State, Nigeria.

\subsection{Preparation of slurries}

The water hyacinth was chopped, blended, $1 \mathrm{~kg}$ was weighed and added to $3 \mathrm{~kg}$ of fresh cow dung this was mixed with appropriate volume of clean water to form slurry. A sterilized rod was used for proper mixing of the slurry; this was fed into the digester through the inlet orifice. The slurry was poured into the digester (tilted to facilitate loading) through the inlet pipe until it started coming out from the outlet pipe. The inlet, outlet, and gas pipe were closed tightly and the digester was then left to stand vertically for twenty one days for the gas to be generated.

\subsection{Cow dung and water hyacinth analysis}

Microbial population of cow dung and water hyacinth were determined separately on the first day before mixing and during digestion process. The population of microbes mainly bacteria and fungi were determined by using nutrient agar for bacteria enumeration and potatoes dextrose agar for fungi and yeast.

\subsubsection{Microbial isolation}

One gram (1g) of each sample was macerated in $9 \mathrm{ml}$ of sterile physiological saline and diluted serially. Then $1 \mathrm{ml}$ and $0.1 \mathrm{ml}$ was pipette from each dilution factor unto sterile Petri-dishes. Thereafter, $20 \mathrm{ml}$ of nutrient agar and acidified potato dextrose agar was cooled to $45^{\circ} \mathrm{C}$ and poured separately onto each of the plates in triplicate and the plates were gently swirled and allowed to solidify. The nutrient agar plates were incubated in an inverted position at $37^{\circ} \pm 2^{\circ} \mathrm{C}$ for 24 hours (bacteria) while potato dextrose agar plates were incubated at $28^{\circ} \pm 2^{\circ} \mathrm{C}$ for 72 hours (fungi). The viable colonies were sub cultured from mixed culture plate to obtain a pure culture. Bacteria cultures were characterized and identified using various morphological and biological tests such as Gram stain, spore stain, motility, catalase, coagulase, indole, urease, citrate, oxidase and sugar fermentation. Pure cultures of each isolate were obtained by streaking the specific colonies on suitable media and incubated appropriately; these were maintained in an agar slant in McCartney bottles. The identification of the microbial isolates was based on classification Scheme proposed by Harrigan and McCance [7], Collins and Lyne [8] and 
Holt et al. [9]. The identification was based essentially on morphological and biochemical reactions. The isolated fungi were then identified with reference to Barnet and Hunter [10], Rhode and Hartman [11] and Frazier and Westhoff [12].

The temperature of the cow dung and blended water hyacinth mixture was measured using a mercury thermometer calibrated in degree centigrade. The temperatures and $\mathrm{pH}$ were determined every two days. The $\mathrm{pH}$ of cow dung and the blended water hyacinth was determined by using a $\mathrm{pH}$ meter. The details of the experiment and analysis of biogas production was as described in previous works by Garba et al. [13]. The compositions of biogas produced were analyzed with gas chromatography.

\section{Results}

Table 1 represents the population of microorganisms in the materials used for the production of biogas water hyacinth, cow dung and slurry produced from mixture of the materials used just before digestion.

Table 1: Microbial population of materials before digestion.

\begin{tabular}{|l|l|l|l|}
\hline Materials & Bacteria $(\mathrm{cfu} / \mathrm{ml})$ & Fungi $(\mathrm{sfu} / \mathrm{ml})$ & Yeast $(\mathrm{cfu} / \mathrm{ml})$ \\
\hline Water hyacinth & $7.4 \times 10^{4}$ & $5.2 \times 10^{4}$ & $4.2 \times 10^{3}$ \\
\hline Cow dung & $3.5 \times 10^{4}$ & $2.8 \times 10^{4}$ & $2.5 \times 10^{3}$ \\
\hline Slurry & $7.8 \times 10^{4}$ & $5.6 \times 10^{4}$ & $4.1 \times 10^{3}$ \\
\hline
\end{tabular}

\section{Discussion}

Anaerobic digestion is a simple process that can greatly reduce the amount of organic matter which might otherwise be destined to be land filled or burnt in the incinerator. Almost any organic material can be processed with anaerobic digestion. This includes biodegradable waste materials such as waste paper, leftover food, sewage and animal wastes. The gases produced are methane, carbon dioxide, carbon monoxide, hydrogen sulphide and other gases in traces. The population of the microorganisms before the anaerobic digestion in Table 1 shows the bacteria population in water hyacinth and cow dung to be $3.5 \times 10^{4}$ and $7.4 \times 10^{4} \mathrm{cfu} / \mathrm{ml}$ respectively while the fungal population were $2.8 \times 10^{4}$ and $5.2 \mathrm{x}$ $10^{4} \mathrm{sfu} / \mathrm{ml}$ respectively. There was extremely limited growth of yeast in the water hyacinth which was $2.5 \times 10^{3} \mathrm{cfu} / \mathrm{ml}$ and cow dung $4.2 \times 10^{3}$. At the initial stage before digestion, the bacteria load of cow dung and cow slurry were $7.8 \times 10^{4}$ and $5.6 \times 10^{4}$ respectively.

Table 2 shows the population of microorganisms contributing to the anaerobic digestion at an isolation interval of 3 days, the digestion period ranges from day 1 to the day 21. The fungal load decreases as the digestion days increases while the yeast growth was not detected at the later days of the digestion. At the beginning of the digestion process, the bacteria load of the slurry was $1.8 \times 10^{5} \mathrm{cfu} / \mathrm{ml}$; the fungal load was $4.1 \times 10^{4} \mathrm{sfu} / \mathrm{ml}$ while the yeast was $1.3 \times 10^{3} \mathrm{cfu} / \mathrm{ml}$. As the digestion proceeds, the bacterial load increased and later dropped towards the end of the digestion. The fungal load decreased from the beginning to the end of the 
digestion while the yeast was no longer detected from the $4^{\text {th }}$ day to the end of the digestion. This might be as a result of the anaerobic condition of the organisms which did not favour their growth.

Table 2: Microbial population contributing to the digestion of biogas.

\begin{tabular}{|c|l|l|l|}
\hline Days & Bacteria $(\mathrm{cfu} / \mathrm{ml})$ & Fungi $(\mathrm{sfu} / \mathrm{ml})$ & Yeast $(\mathrm{cfu} / \mathrm{ml})$ \\
\hline 1 & $1.8 \times 10^{5}$ & $4.1 \times 10^{4}$ & $1.3 \times 10^{3}$ \\
\hline 3 & $3.6 \times 10^{5}$ & $3.8 \times 10^{4}$ & $2.8 \times 10^{4}$ \\
\hline 5 & $5.2 \times 10^{5}$ & $3.5 \times 10^{4}$ & $0.5 \times 10^{3}$ \\
\hline 7 & $5.1 \times 10^{5}$ & $3.0 \times 10^{4}$ & 0 \\
\hline 9 & $4.7 \times 10^{5}$ & $2.7 \times 10^{4}$ & 0 \\
\hline 11 & $4.5 \times 10^{5}$ & $2.5 \times 10^{4}$ & 0 \\
\hline 13 & $3.8 \times 10^{5}$ & $1.7 \times 10^{4}$ & 0 \\
\hline 15 & $2.6 \times 10^{5}$ & $1.3 \times 10^{4}$ & 0 \\
\hline 17 & $2.1 \times 10^{5}$ & $0.9 \times 10^{4}$ & 0 \\
\hline 19 & $1.8 \times 10^{5}$ & $0.5 \times 10^{4}$ & 0 \\
\hline 21 & $1.7 \times 10^{5}$ & $0.4 \times 10^{4}$ & 0 \\
\hline
\end{tabular}

Figure 1 shows the temperature of the environment and the digester during the digestion process. The initial temperature of the digester, ambient and cow slurry were $33^{\circ} \mathrm{C}, 33^{\circ} \mathrm{C}$ and $32^{\circ} \mathrm{C}$. The increase and decrease in the temperature range was due to the environmental condition. The temperature ranges from $30^{\circ} \mathrm{C}$ to $38^{\circ} \mathrm{C}$ throughout the digestion process. The temperature obtained was within the mesophilic range with an average temperature of $33^{\circ} \mathrm{C}$. Methanogens are inactive in extremely high or low temperature and when ambient temperature is $33^{\circ} \mathrm{C}$ or less, the average temperature is within the digester remains not higher $4^{\circ} \mathrm{C}$ above the ambient temperature (Lund [14]).

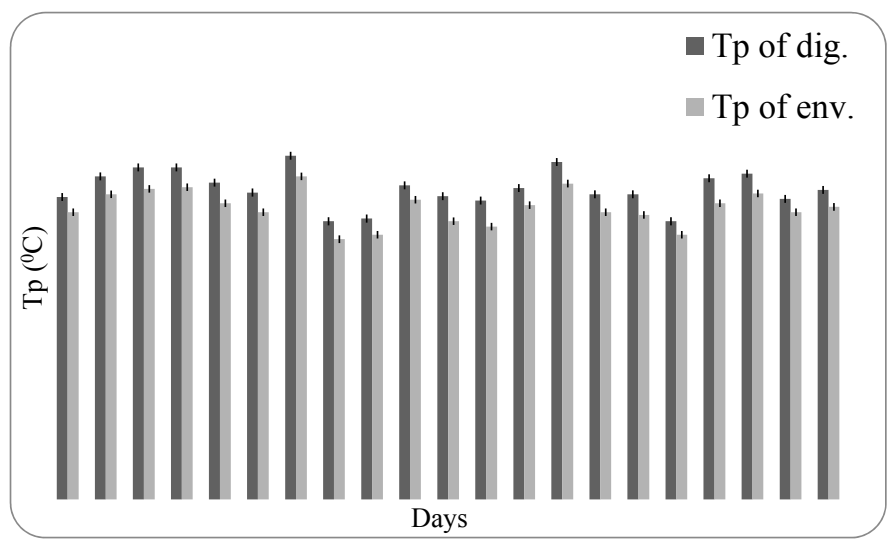

Figure 1: Temperature changes of the digesting materials and the environment. (Key: $\mathrm{Tp}=$ temperature, dig. $=$ digesting materials, env. $=$ environment.) 
The $\mathrm{pH}$ of the anaerobic digestion was shown in Table 3. The initial $\mathrm{pH}$ of the cow dung and the slurry were 6.97 and 6.90 respectively. The $\mathrm{pH}$ ranges from 5.40 to 7.28 and at the initial stage of anaerobic digestion; there was low production of biogas due to the low $\mathrm{pH}$ at the beginning of the digestion process. This might be as a result of the large amounts of organic acids produced by acid forming bacteria. Anaerobic digestion will occur best within the $\mathrm{pH}$ range of 6.8 to 8.0, more acidic or basic mixtures will ferment at a lower speed. The introduction of raw materials will often lower the $\mathrm{pH}$ thereby making the mixture more acidic. This may be a function of the retention time and may also be due to concentration of ammonium which increases as a result of digestion of nitrogen which can increase the $\mathrm{pH}$ value (Marchiam [15]).

The suspected organisms isolated were Escherichia coli, Methanococcus mazei, Enterobacter aerogenes, Clostridium perfringens, Methanobacterium ruminantium, Lactobacillus delbrueckii, Methanothrix sochngeni, Klebsiella pneumoniae, Pseudomonas aeruginosa, Bacillus subtilis and Staphylococcus aureus. All these bacteria were able to survive the mesophilic temperature of digestion. Klebsiella pneumoniae, Enterobacter aerogenes and Bacillus subtilis survived and enhanced the production of biogas even though they are nonmethanogens. These can withstand mesophilic temperature range of the digesting materials and affect the $\mathrm{pH}$ of the anaerobic digestion since they are known to be acid forming bacteria, thereby contributing to the initial stage of the digestion to produce organic acids, peptides, glucose and other monosaccharides which will be utilized during fermentation leading to gas production. Pseudomonas aeruginosa is an extremely adaptable organism that utilizes organic compounds for growth, it is widely distributed in nature as saprophytes and they contribute to the decomposition of the mixture of cow dung and water hyacinth to produce biogas and the by-products. The fungi isolated were: Aspergillus fumigatus, Aspergillus niger, Rhizopus stolonifer, Mucor mucedo, Aspergillus flavus and Cladosporium cladosporoides. These are capable of utilizing a variety of substance.

Table 3: $\mathrm{pH}$ changes of the digesting materials during digestion.

\begin{tabular}{|l|l|}
\hline Days & $\mathrm{pH}$ \\
\hline 1 & $7.04^{\mathrm{g}} \pm 0.01$ \\
\hline 3 & $6.95^{\mathrm{e}} \pm 0.01$ \\
\hline 5 & $6.45^{\mathrm{d}} \pm 0.12$ \\
\hline 7 & $5.67^{\mathrm{b}} \pm 0.01$ \\
\hline 9 & $5.40^{\mathrm{a}} \pm 0.01$ \\
\hline 11 & $6.20^{\mathrm{c}} \pm 0.01$ \\
\hline 13 & $6.45^{\mathrm{d}} \pm 0.01$ \\
\hline 15 & $6.91^{\mathrm{d}} \pm 0.01$ \\
\hline 17 & $7.15^{\mathrm{h}} \pm 0.01$ \\
\hline 19 & $7.28^{\mathrm{i}} \pm 0.62$ \\
\hline
\end{tabular}

Values that are followed by similar alphabets along the same column are not significantly different: 
$\mathrm{pH}$ of cow dung $=6.97$

$\mathrm{pH}$ of water hyacinth $=6.20$

$\mathrm{pH}$ of slurry before digestion $=6.9$

The addition of water hyacinth to cow dung for the biogas production boosted the quality of methane produced. Cow dung gas is usually composed of 55-65\% methane, 30-35\% carbon dioxide, 0-5\% hydrogen sulphide with some hydrogen, nitrogen and other traces (Subba Rao [6]). In a previous study by Adegunloye and Oladejo [16], the addition of crop wastes to the poultry dung (1:4) for the production of biogas greatly increase the methane value to $74.81 \%$ and reduce $\mathrm{CO}_{2}$ value to $8.14 \%$. Table 4 shows an increase in the production of methane $\left(\mathrm{CH}_{4}\right)$, to be $91.10 \%$, other gases were in extremely low amount compared to extremely high amount of methane produced and there was no production of ammonia $\left(\mathrm{NH}_{3}\right)$. This result indicated that the quality of methane gas is better than when only proportions of cow dung were used without the water hyacinth.

Table 4: $\quad$ Percentage composition of biogas produced from water hyacinth and cow dung.

\begin{tabular}{|l|l|}
\hline Name of gas & Percentage $(\%)$ \\
\hline Methane $\left(\mathrm{CH}_{4}\right)$ & 91.10 \\
\hline Ammonia $\left(\mathrm{NH}_{3}\right)$ & 0.00 \\
\hline Carbon monoxide $(\mathrm{CO})$ & 1.34 \\
\hline Hydrogen sulphide $\left(\mathrm{H}_{2} \mathrm{~S}\right)$ & 1.11 \\
\hline Carbon dioxide $\left(\mathrm{CO}_{2}\right)$ & 0.02 \\
\hline Trace gases & 6.43 \\
\hline
\end{tabular}

\section{Conclusion}

This study clearly showed that, the production of biogas with high methane content can be enhanced or increased by the addition of water hyacinth. The water hyacinth is a plant that has abundant nitrogen content and used as substrate for biogas production and the sludge obtained from the biogas. The cow dung is a biodegradable waste as it is cheaply available and found all year round in our environments and their utilization will generate biogas energy for domestic uses such as cooking, heating and refrigeration. This generated energy will save labour and reduce the stress of buying or gathering fire woods, thus helping to ameliorate deforestation problem in Nigeria.

\section{Acknowledgement}

The author will like to acknowledge the people of Igbokoda in Ilaje, Ondo State, Nigeria for their assistance in getting the water hyacinth used for this work. 


\section{References}

[1] Joyce, J. C. Aquatic weeds. The ecology and management of nuisance aquatic vegetation. Oxford University press. p. 11, (1990).

[2] Reza, A and Khan, J. Water hyacinth as cattle feed. Indian Journal of Animal Science. 51: 702-706, (1981).

[3] Hentges, J .F, Salveson, R E, Shirley R L and Moore J E. Processed aquatic plants in cattle diets. Journal of Animal Science. 34: 360, (1972).

[4] El-Serafy, A. M., Soliman, H. S. H., Khattab, H .M., El-Ashry, M. A and Swidan, F .Z Dry matter intake and nutrients digestibility of water hyacinth hay, haylage and silage by buffalo steers. Indian Journal of Animal Science. 57: 698-701, (1981).

[5] Wulf, $\mathrm{K}$ and Andjelic, M Lake Victoria: A Case in International Cooperation. Food and Agriculture Organization of the United Nations. (2000).

[6] Subba Rao, N. S. Soil Microbiology. Oxford 1BH publishing Co. Put. LTD New Delhi, pp. 267-269, (1999).

[7] Harrigan, W. F and McCance, M. E Laboratory Methods in food and diary Microbiology. Academic press, London. p. 452, (1976).

[8] Collins, C. H and Lyne, P. M Microbiological Methods. $5^{\text {th }}$ Ed. Butterworth and Co. Publisher Ltd. London 331-345, (1984).

[9] Holt, J.G., Krieg, N.R., Sneath, P.H., Stanley, J.J and Williams, S.T. Bergeys manual of determinative bacteriology. Wilkins Publishers, Baltimore $3^{\text {rd }}$ edition. (1994).

[10] Barnet, H.L and Hunter, B. H. Illustrated general of imperfecti. $3^{\text {rd }}$ edition. Burgress Publishing Company, Minneapolis, pp. 100-130, (1983).

[11] Rhode, B and Hartman, G. Introducing mycology by examples. Schering Aktiengesell Shaft Press Hamburg, pp. 84-121, (2002).

[12] Frazier, W. C and Westhoff, D. C Food Microbiology. $4^{\text {th }}$ ed. International edition Mc Graw Hill, Singapore pp. 440-441, (1998).

[13] Garba, B., Sambo, A.S. and Abdulrahman, F.M. Studies on Biogas production from fresh cow dung and effect of some parameters on its generation. Paper presented at 8th Annual Conf of Chemical of Nig. Kano. (1994).

[14] Lund, M. S. Building of flexibility Bag Biogas Digester in Tanzania. Technical report University of Denmark, Copenhagen. (1996).

[15] Marchiam, C.G. Principles and practices for Biogas systems, World Bank. (1986).

[16] Adegunloye, D. V and Oladejo, B. O. Effect of ratio variation of crop wastes on the production of poultry dung bio-gas. Nigerian J. of Parasitology. 31 [2] 130-134, (2010). 